\title{
Retraction Notice
}

\section{RETRACTED: UNSUR KEMASLAHATAN PADA HIBAH SUAMI - ISTRI}

\author{
Muhammad Zainuddin Sunarto \\ Universitas Nurul Jadid Paiton Probolinggo \\ zain2406@gmail.com
}

\section{Retracted}

Following a rigorous, carefully concerns and considered in the review of the article published in Al-Qadha: Jurnal Hukum Islam Dan Perundang-Undangan entitled "UNSUR KEMASLAHATAN PADA HIBAH SUAMI - ISTRI" Vol. 7 No. 1, Juni 2020, pp. 43-59, DOI: https://doi.org/10.32505/qadha.v7i1.1470.

The editor found that the article had been published in jurnal Maqashid: Jurnal Hukum Islam Vol. 3 No. 1, Mei 2020, pp. 96-144, DOI: https://doi.org/10.35897/maqashid.v3i1.381.

The document and its content have been removed from Al-Qadha: Jurnal Hukum Islam Dan Perundang-Undangan, and reasonable effort should be made to remove all references to this article. 